\title{
Communication
}

[Comunicação]

\section{Detection of icaA, icaD, and bap genes and biofilm production in Staphylococcus aureus and non-aureus staphylococci isolated from subclinical and clinical bovine mastitis}

\author{
[Detecção dos genes icaA, icaD e bap e produção de biofilme por Staphylococcus aureus \\ e estafilococos não-aureus isolados de mastite clínica e subclínica bovina] \\ A. Salina ${ }^{1}$, F.F. Guimarães ${ }^{1}$, V.B. Richini Pereira ${ }^{2}$, B.D Menozzi ${ }^{1}$, \\ V.L.M. Rall ${ }^{3}$, H. Langoni ${ }^{1 *}$
${ }^{1}$ Universidade Estadual Paulista Júlio de Mesquita Filho - (Unesp) - Faculdade de Medicina
Veterinária e Zootecnia, Botucatu, SP
${ }^{2}$ Instituto Adolfo Lutz - Bauru, SP
${ }^{3}$ Universidade Estadual Paulista Júlio de Mesquita Filho - (Unesp) - Instituto de Biociências - Botucatu, SP

Staphylococcus spp. are the most prevalent bacteria isolated from bovine mastitis. The pathogenesis of Staphylococcus spp. can be attributed to virulence factors responsible for facilitating adhesion within the mammary gland, causing chronic infections (Fox et al., 2005). Non-aureus staphylococci (NAS) species are reported in the literature as minor pathogens involved in mastitis but are very frequently isolated in intrammamary infections (Taponen and Pyörälä, 2009). However, they have been isolated in cases of mastitis, even in farms that have adopted effective programs to control $S$. aureus and Streptococcus agalactiae.

The presence of biofilms has been considered the basis for persistence of chronic infections by these strains (Cucarella et al., 2004). Studies have demonstrated that NAS species are able to form biofilms like $S$. aureus does, but they are less invasive (Taponen and Pyörälä, 2009). Biofilm formation involves two steps: the adhesion of bacteria on the surface of the mammary gland mediated by a capsular antigen called capsular polysaccharide/adhesin (PS/A), followed by accumulation, maturation, and separation phases associated with the production of polysaccharide intercellular adhesion (PIA),

Recebido em 24 de janeiro de 2019

Aceito em 6 de janeiro de 2020

*Autor para correspondência (corresponding author)

E-mail: hélio.langoni@unesp.br essential to the spread of the staphylococci (Simojoki et al., 2012).

Cell proliferation and biofilm formation are known virulence factors mediated by the presence of the ica locus, comprisings four genes, icaA, icaD, icaB, and icaC, organized in an operon $(i c a A D B C)$ with the regulatory gene $i c a \mathrm{R}$. This operon is responsible for expression of PIA, present in the cell wall. The surface protein BAP (biofilm-associated protein) is responsible for promoting the primary fixation in inert surfaces. The expression of bap leads to biofilm formation even without the presence of the $i c a A D B C$ operon. In dairy herds, there is an evidence of the importance of bap in mastitis caused by S. aureus (Cucarella et al., 2004).

The aim of the present study was to verify the biofilm production by $S$. aureus and NAS isolates derived from subclinical and clinical bovine mastitis cases and evaluate the presence of icaA, icaD, and bap in these isolates by PCR. Biofilm production was evaluated on congo red agar and microtiter plate. We also determined whether the presence of biofilm production genes influenced milk somatic cell count (SCC). This research was approved by the Ethics Committee on Animal Use of São Paulo State University (Unesp) CEUA 167/2014. 
The samples were isolated from milk obtained from two dairy farms in the state of São Paulo, Brazil. A total of nine monthly visits were performed in order to obtain 100 strains of $S$. aureus from subclinical mastitis cases and 100 strains of NAS, being 92 from subclinical mastitis cases and eight from clinical mastitis cases. A total of 749 samples of bovine milk were analyzed. The California mastitis test (CMT) was performed to detect subclinical mastitis. The SCC of the milk samples was performed by flow cytometry on Somacount $300^{\circledR}$ equipment.

Ten microliters of the milk samples were plated on 5\% blood agar and MacConkey agar and incubated at $37^{\circ} \mathrm{C}$ under aerobic conditions for 24-48h. Only pure Staphylococcus colonies were used. All isolates were identified as genus Staphylococcus based on colony morphology, Gram staining, and catalase reaction. After confirmation of the genus Staphylococcus, the enzyme coagulase was characterized in all isolates in tubes using tube methods. Other coagulase-positive Staphylococcus species were differentiated from $S$. aureus by mannitol fermentation and susceptibility to $5 \mu \mathrm{g}$ of novobiocin and 300IU of polymyxin B. Nonaureus staphylococci was differentiated from Kokuria based on an oxidation test, fermentation of glucose, by resistance to bacitracin $(0.04 \mathrm{U})$ and by sensitivity to furazolidone (100mg) (Baker, 1984).

Biochemical tests were performed in order to identify Staphylococcus spp., including sugar fermentation (xylose, arabinose, sucrose, trehalose, maltose, mannitol, lactose, xylitol, ribose, fructose, and mannose), production of hemolysin, nitrate reduction, presence of urease and ornithine decarboxylase, and resistance to novobiocin. DNA Extraction. Bacterial DNA was obtained after cultivation of the bacteria in $5 \mathrm{~mL}$ BHI (brain heart infusion). The extraction was performed with an Illustra Blood GenomicPrep Mini Spin Kit (GE Healthcare, Chalfont St. Giles, UK) according to the manufacturer's specification.

For amplification of icaA and icaD genes, primers and the polymerase chain reaction (PCR) protocol was performed according to Vasudevan et al. (2003). For the bap primers and gene amplification, the method described by Cucarella et al. (2004) was used. Staphylococcus aureus ATCC 25923 was used as positive control for amplification of the icaA and icaD genes. An isolate obtained in this study was used as a positive control for the bap gene, which was positive by PCR with amplification of a $971 \mathrm{bp}$ product and sequenced (GenBank accession number AY220730). For a negative control, $S$. epidermidis ATCC 12228 was used for all reactions.

Qualitative detection of biofilm formation by the isolated strains was evaluated on CRA plates according Freeman et al. (1989). Biofilm production on MtP was analyzed according to Vasudevan et al. (2003) with minor modifications. All Staphylococcus spp. previously grown in BHI were standardized using the MacFarland scale $\left(150 \times 10^{6}\right.$ cells $\left./ \mathrm{mL}\right)$. For each sample for both $S$. aureus and NAS, $200 \mu \mathrm{L}$ of the diluted bacteria were inoculated into four wells, including positive and negative controls, and non-inoculated BHI, in order to extract the values of the non-inoculated BHI after reading in optical density. The optical density was determined using an ELISA reader (Labsystems, Multiskan EX) with a 540nm filter. Strains that produced mean absorbance values greater than 0.1 were considered positive for biofilm production.

Frequency distributions were used to describe the percentage of strains of $S$. aureus that contain the genes responsible for biofilm production. The chi-square or Fisher's exact test were used to compare the proportions of strains producing biofilms with the intensity of the subclinical cases. Analysis of variance was used to compare the means of SCC values in logarithmic scale of basis $10(\log (10)$ cells $/ \mathrm{mL})$ between strains with or without the identified genes. Statistical analyses were performed with SAS 9.2 with statistical significance determined at the level of 0.05 .

A CMT score of 3 was more often found in $S$. aureus $(62 \%)$ as well as in NAS $(55 \%)(\mathrm{P}=0.02)$. The average of the results obtained for SCC were higher for $S$. aureus isolates $(5.88 \pm 0.59)$ than for NAS isolates $(5.71 \pm 0.36)$ with $\mathrm{P}=0.02$.

All samples were classified in the same way using two phenotypic tests. The 100 isolates of staphylococci isolated from mastitic milk were 
tested for biofilm genes and subsequent biofilm formation. Among of 100 NAS isolates, the most frequently identified species was Staphylococcus xylosus observed for $51 \%$ isolates, and Staphylococcus simulans in $24 \%$ of isolates, followed by: Staphylococcus warneri (9\%), Staphylococcus haemolyticus (5\%), Staphylococcus hominis subsp. hominis (4\%), Staphylococcus lugdunensis (3\%), Staphylococcus capitis (1\%), Staphylococcus cohnii subsp. urealyticum (1\%), Staphylococcus epidermidis (1\%), Staphylococcus caprae (1\%). The distribution of the frequencies of icaA, icaD, and bap genes in $S$. aureus isolates were 82,83 , and $58 \%$, respectively. Among the 100 isolates of $S$. aureus, $56 \%$ contained all three genes.

A total of $25(25 \%) S$. aureus isolates produced biofilms on CRA, and $17(68 \%)$ of these had the ica $\mathrm{AD}$ genes. Both bright black colonies and black colonies were a positive result on CRA. Two isolates of $S$. aureus produced biofilm on CRA without the presence of any of the investigated genes. The positive rate on MtP was $15 \%$. Of the $82 \mathrm{~S}$. aureus isolates possessing the icaA gene in the genotypic test, only $13(15.8 \%)$ were positive for biofilm formation using MtP. For the 83 strains with the icaD gene, the positive rate was $13(15.6 \%)$. There was no association between the presence of icaAD genes and biofilm formation in CRA or $\operatorname{MtP}(\mathrm{P}=1.0)$. There was no relationship between the presence of the bap gene and biofilm formation in the MtP assay once only 12 strains with bap gene $(20.7 \%)$ showed biofilm formation $(\mathrm{P}=0.08)$.

A total of $8 \%$ of the NAS isolates produced biofilms on CRA and $41 \%$ on MtP; however, none of them possessed the investigated genes. According to Fisher's test, the ability of the isolates of NAS to form biofilm was not different when comparing the results from CRA and MtP $(\mathrm{P}>0.05)$ The agreement between the two phenotypic tests was poor $(\mathrm{K}=-0.11)$. From the $75 \mathrm{~S}$. aureus isolates negative on CRA, 62 $(82.7 \%)$ were also negative for the MtP test. Among the 15 positive isolates in the adhesion test, only two, which represented $13.3 \%$ of the isolates were also positive in CRA.

The primers used for detection of icaA and icaD were described previously by Vasudevan et al. (2003) and were also used by Simojoki et al. (2012). These primers work well for recognition of $S$. aureus strains but failed to recognize $S$. epidermidis (ATCC 35984), a strain known to be positive for both genes. In the present study, only one isolate of $S$. epidermidis was obtained, and it is inappropriate to affirm that the primer used by Simojoki et al. (2012) is ineffective for the other species obtained too.

Thus, it emphasizes the need for use of standard strains for all species isolated in this present study in order to confirm the affirmation obtained by Simojoki et al. (2012). The same authors did not find the bap gene in 84 samples of Staphylococcus spp. isolated from bovine mastitis.

Two strains of $S$. aureus were able to produce biofilms without the presence of the investigated genes. Chaieb et al. (2005) previously found a strain that was negative for both genes (icaA and icaD) but produced some black colonies on CRA. It became apparent to Chaieb et al. (2005) that biofilm formation may be associated with other factors, not only the presence of the icaA and icaD genes. It also suggests that other regulatory genes or other genes involved in biofilm formation may be present in these strains, stimulating the production of PIA or other surface proteins can contribute to bacterial adhesion.

The bap gene, carried by a transposon present in the mobile pathogenicity island SaPIbov2 present only in $S$. aureus isolates of bovine origin, contributes to the pathogenic roles in persistent infections (Cucarella et al., 2004). The presence of the bap gene confers chronicity to cases of mastitis, but $S$. aureus can form biofilms even without bap. These species may possess virulence factors, such as the expression of genes like $a g r$ that regulate staphylococcal membrane proteins that are able to promote the adhesion of these microorganisms to inert surfaces (Vautor $e t$ al., 2007).

In the present study, the higher positive rate obtained for the $S$. aureus strains was on CRA compared to the MtP test, with $25 \%$ and $15 \%$, respectively. This result agrees with the study by Los et al. (2010), which compared the results of positive strains on CRA and MtP, obtaining $58.9 \%$ positive on CRA and $35.6 \%$ on MtP. In Brazil, Costa Krewer et al. (2015) obtained positivity of $3.7 \%$ of isolates of $S$. aureus, other 
coagulase-positive staphylococci and NAS on CRA and $96.3 \%$ of Staphylococcus spp. positives on MtP. The agreement between the phenotypic tests evaluated in this study was poor, with only two positive samples of $S$. aureus in both tests.

It is noteworthy that in the present study, biofilm production was evaluated by two phenotypic tests. Other methods of identifying strains of biofilm-positive staphylococci can be used, such as fluorescent in situ hybridization protocol (Simojoki et al., 2012).
The present study demonstrated that biofilm production in NAS isolates may be associated with factors other than the icaA, icaD, and bap genes, stimulating biofilm production in vitro. We did not observe a relationship between the presence of surveyed genes and SCC in S. aureus samples. Further studies can be performed in order to elucidate other factors involved in biofilm formation in NAS species.

Keywords: Staphylococcus aureus, non-aureus staphylococci, red agar congo, bovine mastitis

\section{RESUMO}

Algumas espécies de Staphylococcus causam infecções crônicas intramamárias e podem levar à formação de biofilme. No presente estudo, levantou-se a hipótese de que as espécies de Staphylococcus isolados da mastite bovina são capazes de formar biofilme in vitro associado à presença dos genes icaA, icaD ou bap. Um total de 200 isolados de Staphylococcus, sendo 100 Staphylococcus aureus de casos de mastite subclínica e 100 estafilococos não aureus (ENA) de casos de mastite subclínica e clínica, obtidos em duas fazendas leiteiras, no estado de São Paulo, foram avaliados quanto à capacidade de produzir biofilmes in vitro. A presença de icaA, icaD e bap foi confirmada por PCR, e a produção de biofilme em ágar vermelho congo (Congo Red Agar - CRA) e em teste de microplaca (Microtiter Plate - MtP) foi avaliada nos isolados de $\mathrm{S}$. aureus e ENA. Os resultados mostraram a presença dos genes icaA, icaD $e$ bap em S. aureus, mas não em ENA. A produção de biofilme pode estar associada à presença de outros fatores ou genes que estimulam a produção de biofilme in vitro. O ensaio de MtP serve como um modelo quantitativo para o estudo da aderência de espécies de estafilococos associados à mastite bovina.

Palavras-chave: Staphylococcus aureus, estafilococos não aureus, ágar vermelho congo, mastite bovina

\section{ACKNOWLEDGEMENTS}

This work was supported by the FAPESP (The São Paulo State Official Foundation to Support Research), grant number 2013/14383-9.

\section{REFERENCES}

BAKER, J.S. Comparison of various methods for differentiation of staphylococci and micrococci. J. Clin. Microbiol., v.19, p.875-879, 1984.

CHAIEB, K.; MAHDOUANI, K.; BAKHROUF, A. Detection of icaA and icaD loci by polymerase chain reaction and biofilm formation by Staphylococcus epidermidis isolated from dialysate and needles in a dialysis unit. J. Hosp. Infect., v.61, p.225-230, 2005.

COSTA KREWER, C.; AMANSO, E.S.; GOUVEIA, G.V.; LIMA SOUZA, R. et al. Resistance to antimicrobials and biofilm formation in Staphylococcus spp. isolated from bovine mastitis in the Northeast of Brazil. Trop. Anim. Health Prod., v.47, p.511-518, 2015.
CUCARELLA, C.; TORMO, M.A.; ÚBEDA, C.; TROTONDA, M.P. et al. Role of Biofilmassociated protein bap in the pathogenesis of bovine Staphylococcus aureus. Infect. Immun., v.72, p.2177-2185, 2004.

FOX, L.K.; ZADOKS, R.N.; GASKINS, C.T. Biofilm production by Staphylococcus aureus associated with intramammary infection. Vet Microbiol., v.107, p.295-299, 2005.

FREEMAN, D.J.; FALKINER, F.R.; KEANE, C.T. New method for detecting slime production by coagulase negative staphylococci. J. Clin. Pathol., v.42, p.872-874, 1989.

LOS, R.; SAWICKI, R.; JUDA, M.; STANKEVIC, M. et al. A comparative analysis of phenotypic and genotypic methods for the determination of the biofilm-forming abilities of Staphylococcus epidermidis. FEMS Microbiol. Lett., v.310, p.97-103, 2010. 
SIMOJOKI, H.; HYVÖNEN, P.; PLUMED FERRER, C.; TAPONEN, S.; PYÖRÄLÄ, S. Is the biofilm formation and slime producing ability of coagulase-negative Staphylococci associated with the persistence and severity of intramammary infection? Vet. Microbiol., v.158, p.344-352, 2012.

TAPONEN, S.; PYÖRÄLÄ, S. Coagulasenegative staphylococci as cause of bovine mastitis - not so different from Staphylococcus aureus? Vet. Microbiol., v.134, p.29-36, 2009.
VASUDEVAN, P.; NAIR, M.K.M.; ANNAMALAI, T.; VENKITANARAYANAN, K.S. Phenotypic and genotypic characterization of bovine mastitis isolates of Staphylococcus aureus for biofilm formation. Vet. Microbiol., v.92, p.179-185, 2003.

VAUTOR, E.; CARSENTI-DELLAMONICA, H.; SABAH, M.; MANCINI, G. et al. Characterization of Staphylococcus aureus isolates recovered from dairy sheep farms $(a g r$ group, adherence, slime, resistance to antibiotics). Small Ruminant Res., v.72, p.197199, 2007. 